Monika SPOREK ${ }^{1}$

\title{
VOLATILE OIL CONTENT OF SCOTS PINE NEEDLES (Pinus sylvestris L.)
}

\author{
ZAWARTOŚĆ OLEJKÓW ETERYCZNYCH \\ W IGLIWIU SOSNY ZWYCZAJNEJ (Pinus sylvestris L.)
}

\begin{abstract}
This study focused on how the concentration of volatile oils in Scots Pine needles varied in relation to the age of the trees, the age of the needles and their location within the canopy. Study material were pine needles from 15-, 44- and 89-year-old pine stands. The mean content of oils increased with the age of trees. The averaged oil content in needles was: $0.46 \%$ in the 15 -year-old stand, $0.55 \%$ in the 44 -year-old and $0.61 \%$ in the 89 -year-old stands. The mean content of volatile oils decreased with the age of the needles. 1-year-old needles contained the highest concentration of volatile oils $(0.56 \%)$, and the 3-year-old needles contained the least $(0.48 \%)$. In 15 -year-old stands the oil content in needles increased linearly with their height in the canopy. In 44-year-old (age class IIb) and 89-year-old (age class Va) stands oil content was greater lower in the canopy than in the middle.
\end{abstract}

Keywords: essential oil, needles, crown zone, tree age, Scots pine

\section{Introduction}

Volatile oils from pine needles are worth more than any other volatile oil produced in Poland because pine is so common in the country. Studies have shown that many factors affect the quantity of volatile oils in the needles: age of the tree, age of the needles, harvest season, resin collection from the tree, the method the material is prepared for distillation and air pollution [1-4]. Volatile oils are most concentrated in the needles of Scots Pines, but they can also be extracted from shoots, cones, bark and wood. About $40 \mathrm{Mg}$ (tons) of pine oil are produced each year around the world, mostly in China and Russia. Poland provided most of the world's pine oil in the 1960s and 1970s, when the country's yearly production reached $30 \mathrm{Mg}[5]$.

This study set out to determine the volatile oil content of Scots Pine (Pinus sylvestris L.) needles from stands of different ages by collecting 1-, 2- and 3-year-old needles from the bottom, middle and top of the canopy.

\section{Methods}

Pine stands were studied in south-western Poland (forest district Ladek Zdroj, division Trzebieszowice) in the Sudety Mountains climate region. Pine needles were collected from

\footnotetext{
${ }^{1}$ Ecology and Nature Protection Unit, Chair of Biotechnology and Molecular Biology, University of Opole, ul. kard. B. Kominka 6a, 45-035 Opole, Poland, email: mebis@uni.opole.pl
} 
15, 44- and 89-year-old pine stands. In each plot we selected six model trees growing in sites well exposed to light, in habitat defined as mountain fresh mixed forest. In the 15 -year-old stand, needles were collected from the bottom, middle and top of the canopy of standing trees. But in older stands needles were collected only from the bottom and middle zones, because the crown was out of reach. Shoots with needles were collected in the morning on dry days, packed in well-sealed foil bags and taken to the laboratory. There the needles were separated from the stems, were divided into three age classes, and were ground in mixers. Then the material's volatile oil content was measured by steam distillation in Deryng apparatus. 63 samples of $100 \mathrm{~g}$ of fresh needles were analysed, distilling each for 70 minutes from the moment the pulp started boiling.

\section{Results and discussion}

This investigation is part of a study which has been conducted since 2009 on volatile oils in the needles of forest trees, focusing on Scots Pine, but also examining Silver Fir, Norway Spruce and Douglas Fir, in which 400 samples have been analysed. This study, in 2014 , focused on how the concentration of volatile oils in Scots Pine needles varied in relation to the age of the trees, the age of the needles and their location within the canopy [6]. While conducting quantitative analysis of the pine needles' volatile oil content the dynamics of oil excretion during distillation was studied. Half of the oils were excreted within 10 minutes of the pulp boiling and $85 \%$ of the oils were collected during the next 25 minutes.

The mean content of volatile oils in all the needles combined was $0.53 \%$ (minimum $0.29 \%$, maximum $0.96 \%$ ). The mode of the 63 analysed samples was $0.46 \%$ and the median was $0.49 \%$. The mean results of analyses showed a variation of $26 \%$.

The literature reports that the content of volatile oils in conifers' needles varies greatly, even within a species. The content in pine shoots was within a range of $0.3-0.7 \%[1,6]$. All the authors agreed that pine needles collected in locations exposed to air pollution, and from different soils, had different amounts volatile oils whose chemical content also varied [2-4, 7-9].

\section{The effect of trees' age on the volatile oil content in needles}

The effect of trees' age on the volatile oil content of their needles was examined because the literature presents contradictory data on this issue. The study showed that the mean content of oils increased with the age of trees. The needles' oil content averaged $0.46 \%$ in the 15 -year-old stand, $0.55 \%$ in the 44 -year-olds and $0.61 \%$ in the 89 -year-olds (Table 1, Fig. 1).

The literature gives evidence of the opposite relationship [1, 10]. Needles collected from young trees contain more volatile oils than needles from older trees. This refers mostly to the oils obtained from the Silver Fir. Needles of 15-year-old Silver Firs contained on average $40 \%$ more of volatile oil than the 100-year-old trees [10].

Glowacki [1] found a similar relationship in pines in a study from 1991 to 1995 . He determined a mean oil content of $0.54 \%$ in needles from a 5 -year-old pine plantation, $0.52 \%$ in a 15 -year-old stand and $0.38 \%$ in a 100 -year-old stand. In his earlier studies Glowacki [1] had shown an inverse relationship, and pine needles from a 20-year-old stand had contained only $0.32 \%$ of volatile oils but from a 100 -year-old stand as much as $0.55 \%$. Chojnacki and Cichy [7] confirmed that the content of volatile oils increased with the age 
of trees. 2-year-old needles from 15-year-old pines contained from $0.53 \mathrm{~cm}^{3}$ oil/100 $\mathrm{g}$ of dry mass in an area with no industrial emissions to $0.71 \mathrm{~cm}^{3}$ oils $/ 100 \mathrm{~g}$ of dry mass in a zone affected by industry. More oil $\left(0.72 \mathrm{~cm}^{3}\right.$ to $0.78 \mathrm{~cm}^{3}$ per $100 \mathrm{~g}$ of dry mass) was obtained by distillation of 2-year-old needles from a 100 -year-old pine stand.

Table 1

Volatile oil content of Scots Pine (Pinus sylvestris L.) needles in relation to the age of the tree

\begin{tabular}{|c|c|c|c|}
\hline \multirow{2}{*}{$\begin{array}{c}\text { Measures of central } \\
\text { tendency } \\
\text { and disperssion }\end{array}$} & \multicolumn{3}{|c|}{ Age of trees [years] } \\
\cline { 2 - 4 } & $\mathbf{3}$ & $\mathbf{4 4}$ & $\mathbf{8 9}$ \\
\cline { 2 - 4 } & & \multicolumn{3}{|c|}{ Volatile oil content [\%] } \\
\hline $\bar{x}$ & 0.46 & 0.55 & 0.61 \\
\hline$S D$ & 0.115 & 0.146 & 0.108 \\
\hline Min & 0.29 & 0.38 & 0.46 \\
\hline Max & 0.72 & 0.96 & 0.79 \\
\hline Mode & 0.36 & 0.48 & 0.60 \\
\hline Median & 0.44 & 0.48 & 0.60 \\
\hline Coefficient of variation [\%] & 25.06 & 26.71 & 17.53 \\
\hline
\end{tabular}

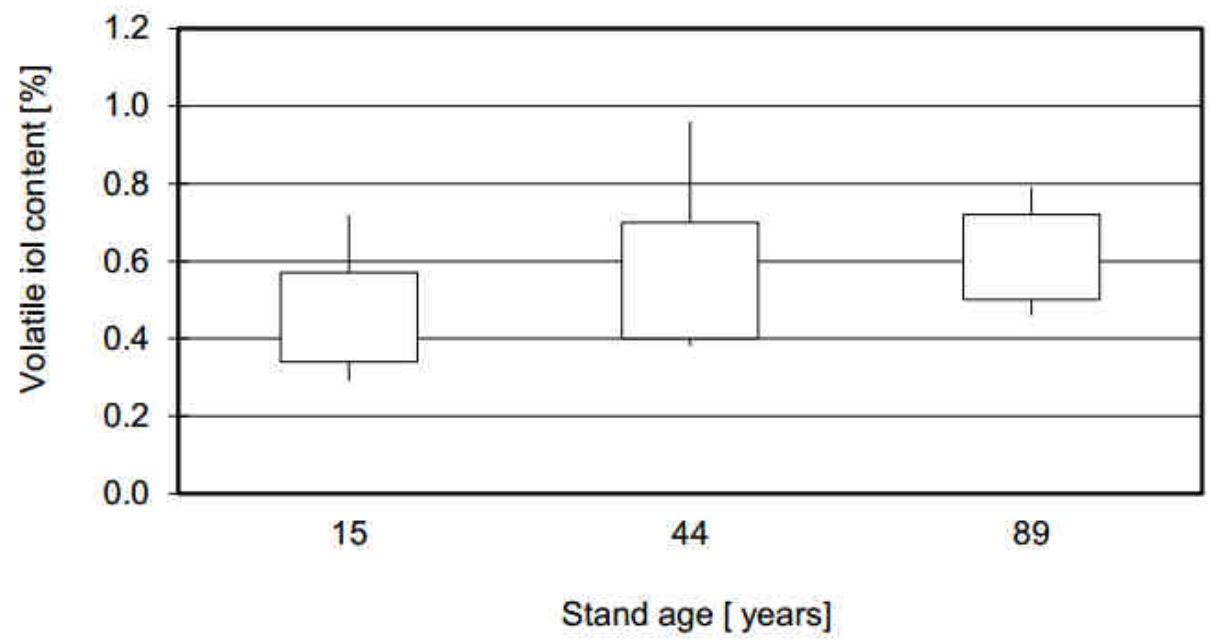

Fig. 1. Volatile oil content of Scots Pine needles in relation to the tree's age

\section{The content of volatile oils in relation to the age of needles}

The mean volatile oil content was compared between 1-, 2- and 3-year-old needles, and it decreased with the needles' age, regardless of the age of trees from which they originated (Table 2, Fig. 2). 1-year-old needles had the highest content $(0.56 \%)$ and 3 -year-old needles the lowest $(0.48 \%)$ (Table 2).

Examining the age of needles and the age of the trees it was found that 1-year-old needles of 15-year-old trees had the lowest oil content $(0.48 \%)$, and 1-year-old needles of 44-year-old trees had the highest $(0.64 \%)$ (Table 3$)$.

In 2-year-old needles, those from the 89-year-old stand had the most oils $(0.70 \%)$, and those from 45-year-old and 15-year-old trees had 0.49\%. 3-year-old needles showed a similar pattern, those from the oldest trees had the highest mean content of oils and those 
from the youngest trees the lowest (89-year-old trees - $0.55 \%$; 45-year-old $-0.52 \%$, 15 -year-old - 0.40\%) (Table 3).

Volatile oil content of Scots Pine (Pinus sylvestris L.) needles by the age of needles collected from 15-, 44- and 89-year-old stands

\begin{tabular}{|c|c|c|c|}
\hline \multirow{3}{*}{$\begin{array}{c}\text { Measures of central } \\
\text { tendency } \\
\text { and disperssion }\end{array}$} & \multicolumn{3}{|c|}{ Age of needles } \\
\hline & 1-year-old & 2-year-old & 3-year-old \\
\hline & \multicolumn{3}{|c|}{ Content of volatile oils [\%] } \\
\hline $\bar{x}$ & 0.56 & 0.55 & 0.48 \\
\hline$S D$ & 0.163 & 0.128 & 0.107 \\
\hline Min & 0.36 & 0.29 & 0.31 \\
\hline $\operatorname{Max}$ & 0.96 & 0.78 & 0.69 \\
\hline Mode & 0.36 & 0.49 & 0.46 \\
\hline Median & 0.53 & 0.51 & 0.46 \\
\hline Coefficient of variation [\%] & 29.30 & 23.35 & 22.31 \\
\hline
\end{tabular}

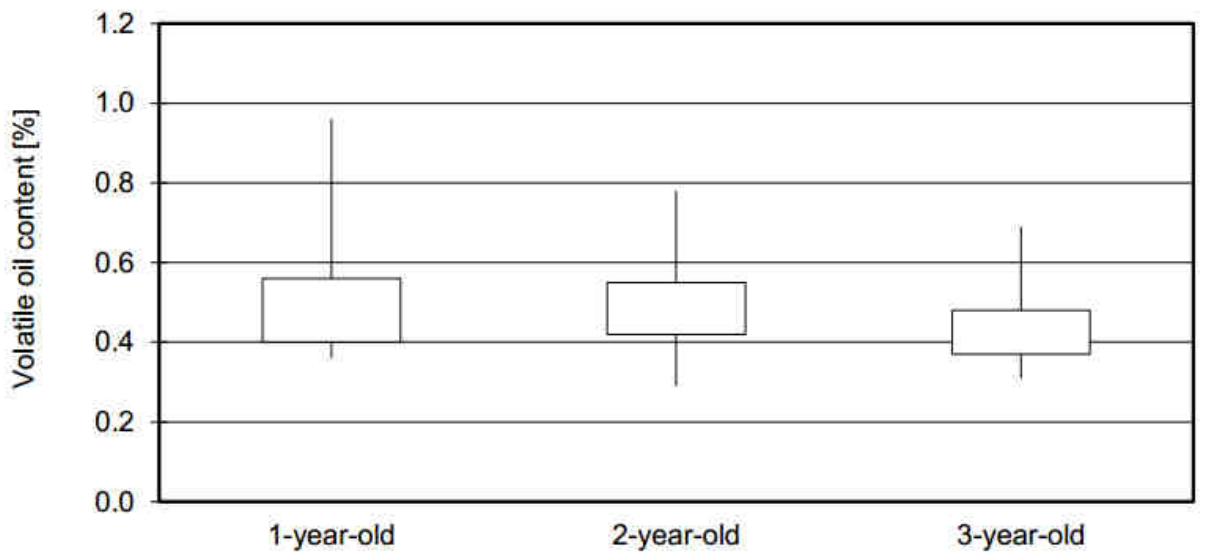

Age of needles

Fig. 2. Volatile oil content of Scots Pine needles in relation to the age of needles

Volatile oil content of 1-, 2- and 3-year-old Scots Pine (Pinus sylvestris L.) needles

\begin{tabular}{|c|c|c|c|c|c|c|c|c|c|}
\hline \multirow{5}{*}{$\begin{array}{c}\text { Measures of } \\
\text { central tendency } \\
\text { and disperssion }\end{array}$} & \multicolumn{9}{|c|}{ Age of needles } \\
\hline & \multicolumn{3}{|c|}{ 1-year-old } & \multicolumn{3}{|c|}{ 2-year-old } & \multicolumn{3}{|c|}{ 3-year-old } \\
\hline & \multicolumn{9}{|c|}{ Age of trees [years] } \\
\hline & 15 & 44 & 89 & 15 & 44 & 89 & 15 & 44 & 89 \\
\hline & \multicolumn{9}{|c|}{ Content of volatile oils [\%] } \\
\hline $\bar{x}$ & 0.48 & 0.64 & 0.59 & 0.49 & 0.49 & 0.70 & 0.40 & 0.52 & 0.55 \\
\hline$S D$ & 0.15 & 0.191 & 0.074 & 0.09 & 0.063 & 0.088 & 0.056 & 0.107 & 0.092 \\
\hline Min & 0.36 & 0.48 & 0.48 & 0.29 & 0.43 & 0.59 & 0.31 & 0,38 & 0.46 \\
\hline $\operatorname{Max}$ & 0.72 & 0.96 & 0.72 & 0.63 & 0.59 & 0.79 & 0.46 & 0.69 & 0.64 \\
\hline Mode & 0.36 & 0.48 & 0.60 & 0.49 & 0.43 & 0.79 & 0.44 & - & 0.64 \\
\hline Median & 0.38 & 0.54 & 0.60 & 0.49 & 0.46 & 0.74 & 0.43 & 0.50 & 0.55 \\
\hline $\begin{array}{l}\text { Coefficient of } \\
\text { variation [\%] }\end{array}$ & 31.66 & 29.97 & 12.64 & 18.98 & 12.82 & 12.52 & 13.87 & 20.58 & 16.67 \\
\hline
\end{tabular}




\section{Volatile oil content in relation to location of needles in the canopy}

Similarly, the oil content in needles collected from the bottom, middle and top of tree canopies was compared. Growth conditions differed, because the studied stands ranged widely in age. The density and cover of the canopy changes as trees age, so access to light also differs, especially at the canopy's base. Study plots and model trees were selected to enable collecting samples from canopies well exposed to light, but the density of a canopy (the proportion of the ecological space it fills) was greatest in the 15-year-old stands (age class Ib). In these stands the needles' oil content increased linearly with their height in the canopy. Needles from the bottom zone contained $0.36 \%$ oils, from the middle $0.46 \%$, and from the top $0.55 \%$ (Table 4, Fig. 3).

Table 4

Volatile oil content of Scots Pine (Pinus sylvestris L.) needles in relation to their canopy zone

\begin{tabular}{|c|c|c|c|c|c|c|c|}
\hline \multirow{5}{*}{$\begin{array}{l}\text { Measures of } \\
\text { central tendency } \\
\text { and disperssion }\end{array}$} & \multicolumn{7}{|c|}{ Age of trees [years] } \\
\hline & \multicolumn{3}{|c|}{15} & \multicolumn{2}{|c|}{44} & \multicolumn{2}{|c|}{89} \\
\hline & \multicolumn{7}{|c|}{ Canopy zones } \\
\hline & Bottom & Middle & Top & Bottom & Middle & Bottom & Middle \\
\hline & \multicolumn{7}{|c|}{ Content of volatile oils [\%] } \\
\hline $\bar{x}$ & 0.36 & 0.46 & 0.55 & 0.65 & 0.44 & 0.68 & 0.55 \\
\hline$S D$ & 0.05 & 0.09 & 0.11 & 0.14 & 0.03 & 0.09 & 0.08 \\
\hline Min & 0.29 & 0.36 & 0.44 & 0.49 & 0.38 & 053 & 0.46 \\
\hline $\operatorname{Max}$ & 0.49 & 0.63 & 0.51 & 0.69 & 0.46 & 0.79 & 0.69 \\
\hline Mode & 0.36 & 0.43 & 0.51 & - & 0.48 & 0.79 & 0.46 \\
\hline Median & 0.36 & 0.43 & 0.51 & 0.60 & 0.43 & 0.64 & 0.59 \\
\hline $\begin{array}{l}\text { Coefficient of } \\
\text { variation }[\%]\end{array}$ & 15.28 & 18.40 & 19.19 & 22.07 & 6.75 & 12.97 & 14.53 \\
\hline
\end{tabular}

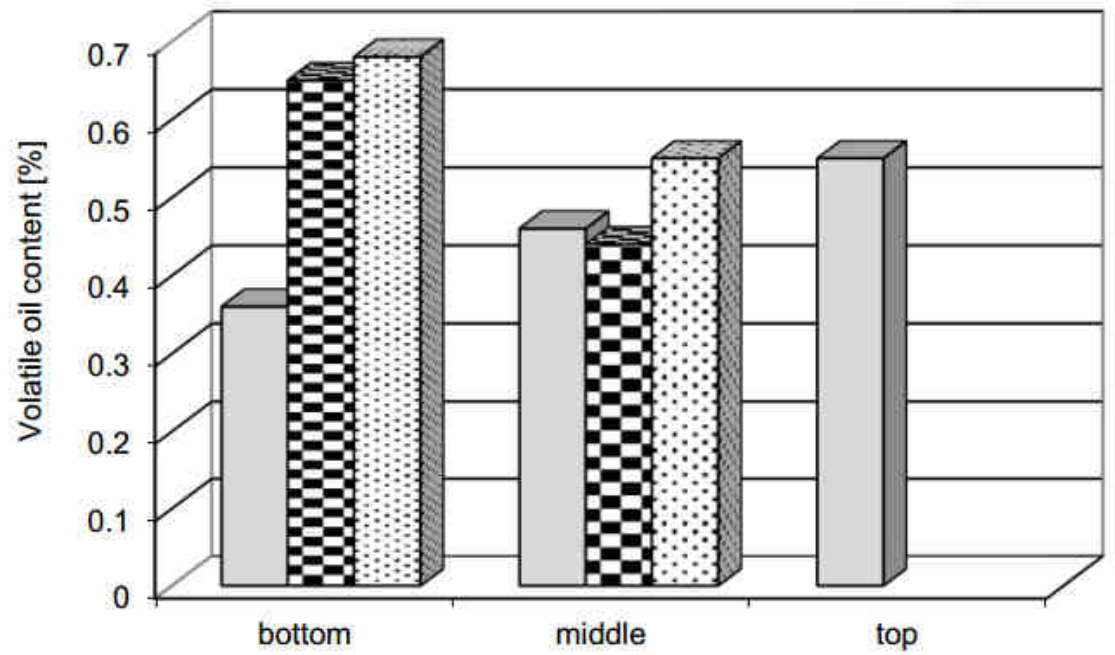

Crown zones
口stand age -15 years
هistand age -44 years
घstand age - 89 years

Fig. 3. Volatile oil content of Scots Pine (Pinus sylvestris L.) needles collected from three zones of the canopy 
But in 44-year-old (age class IIb) and 89-year-old (age class Va) stands, whose crowns were far higher than the younger trees', oil concentrations were highest lower in the canopy -0.65 and $0.68 \%$ respectively, and in the middle 0.44 and $0.55 \%$, respectively (Table 4 ).

The literature provides contradictory data on the content of volatile oils in relation to the needle's location in the canopy. In spruce, the authors [11] obtained similar results to our 15-year-old pine stand, and the volatile oil content increased with height. The top of spruce canopies contained twice as much oils $(0.31 \%)$ as their bottom zones $(0.14 \%)$. Glowacki [12] showed similar relationships. Spruce needles from the top and middle of the canopy contained 0.21 and $0.19 \%$ oils, respectively, but needles from the bottom contained about $40 \%$ less oil $(0.12 \%)$.

\section{Conclusions}

1. The mean content of volatile oils in pine needles increased with the age of the tree.

2. The mean content of volatile oils decreased with the age of the needles. 1-year-old needles contained the highest concentration of volatile oils $(0.56 \%)$, and the 3 -year-old needles contained the least $(0.48 \%)$.

3. The volatile oil content of pine needles of different ages changed in relation to the age of trees.

4. In 15-year-old tree stand (age class $\mathrm{Ib}$ ) the content of volatile oils increased with the height. Needles from the crown had the highest oil content.

5. In 44-year-old (age class IIb) and 89-year-old (age class Va) stands oil content was greater lower in the canopy than in the middle.

\section{References}

[1] Głowacki S. Zawartość olejków eterycznych w igliwiu drzew leśnych. [The content of volatile oils in the needles of forest trees]. Sylwan. 1994;1:27-42. https://sylwan.lasy.gov.pl/apex/ f?p=105:2:::NO:RP,2:P2_ZESZYT:1994_1.

[2] Lehtiö $H$. Effect of air pollution on the volatile oil in needles of Scots pine (Pinus sylvestris L.). Silva Fennica. 1981;15(2):122-129. https://helda.helsinki.fi/bitstream/handle/10138/15051/ 15-No\%202_Lehti\%F6.pdf?sequence=1.

[3] Judzentiene A, Stikliene A, Kupcinskiene E. Changes in the essentional oil composition in the needles of Scots pine (Pinus sylvestris L.) under anthropogenic stress. Scient World J. 2007;7(S1):141-150. DOI: 10.1100/tsw.2007.34.

[4] Kupcinskiene E, Stikliene A, Judzentiene A. The essential oil qualitative and quantitative composition in the needles of Pinus sylvestris L. growing along industrial tranects. Environ Pollut. 2008;155:481-491. DOI: 10.1016/j.envpol.2008.02.001.

[5] Góra J, Lis A. Najcenniejsze olejki eteryczne. [The most valuable volatile oils] Część I. Łódź: Wyd Politechniki Łódzkiej; 2012.

[6] Sporek M. Essential oils in the needles of scots pine (Pinus sylvestris L.). Proc ECOpole. 2014;8(2):43-441. DOI: 10.2429/proc.2014.8(2)077.

[7] Chojnacki B, Cichy W. Zawartość monoterpenów igliwia sosny zwyczajnej (Pinus sylvestris L.) narażonej na działanie emisji przemysłowych. [Content of monoterpenes in etheric oils from foliage of Scots Pine exposed to the action of industrial immisions]. Sylwan. 1995;4:47-55. https://sylwan.lasy.gov.pl/ apex/f?p=105:2:::NO:RP,2:P2_ZESZYT:1995_4.

[8] Judžentienė A, Šližytė J, Stiklienè A, Kupčinskienė E. Characteristics of essential oil composition in the needles of young stand of Scots pine (Pinus sylvestris L.) growing along aerial ammonia gradient. Chemija. 2006;17(2):67-73. http://www.lmaleidykla.lt/publ/0235-7216/2006/4/Che_067_073.pdf.

[9] Neverova OA, Tsandekova OL, Domrachev DV. Study of the composition of ether oils from pine needles of Pinus sylvestris L. growing in various edaphic conditions of Kuzbass surface coal mines dumps. Global J Pharmacol. 2014;8(3):415-419. DOI: 10.5829/idosi.gjp.2014.8.3.83330. 
[10] Półtorak-Kędziołka A. Ocena zawartości olejków eterycznych w cetynie jodłowej. [Assessment of volatile oils in the fir needle fall]. Sylwan. 2003;1:70-77. https://sylwan.lasy.gov.pl/apex/ f?p=105:2:::NO:RP,2:P2_ZESZYT:2003_1.

[11] Barszcz A, Rutkowska L. The effect of a crown zone and an annual shoot increment on the content of volatile oils from spruce branch biomass. Fol Forest Pol. 1993;35:5-13.

[12] Głowacki S. Badania wybranych właściwości cetyny i igliwia świerka pospolitego (Picea abies Karst.) z Wigierskiego Parku Narodowego. [Research on selected properties of twigs and needles of Norway Spruce (Picea abies Karst.) from the Wigry National Park]. Sylwan. 1998;7:53-60. https://sylwan.lasy.gov.pl/ apex/f?p=105:2:::NO:RP,2:P2_ZESZYT:1998_7.

\title{
ZAWARTOŚĆ OLEJKÓW ETERYCZNYCH W IGLIWIU SOSNY ZWYCZAJNEJ (Pinus sylvestris L.)
}

\author{
Samodzielna Katedra Biotechnologii i Biologii Molekularnej, Uniwersytet Opolski
}

\begin{abstract}
Abstrakt: Badania dotyczą zmienności zawartości olejku eterycznego w igliwiu sosny zwyczajnej w zależności od wieku drzew, garnituru igieł oraz jego usytuowania w koronie. Materiał do badań stanowiło igliwie zebrane z drzewostanów sosnowych w wieku 15, 44 i 89 lat. W przeprowadzonych badaniach średnia zawartość olejków wzrastała wraz z wiekiem drzew. W igliwiu pochodzącym z 15-letniego młodnika zawartość olejku wynosiła średnio 0,46\%, a w igliwiu drzewostanów 44- i 89-letnich odpowiednio 0,55 i 0,61\%. Średnia zawartość olejku maleje wraz z wiekiem igliwia. Najwięcej olejku zawiera igliwie jednoroczne - 0,56\%, najmniej igliwie trzyletnie - 0.48\%. W drzewostanie 15-letnim stwierdzono wyraźny wzrost wydajności olejków eterycznych w kierunku od nasady korony do części wierzchołkowej. W drzewostanach starszych (Ilb i Va klasy wieku), gdzie korony są wyżej osadzone, igliwie pobrane z nasady korony zawierało więcej olejku niż z partii środkowej.
\end{abstract}

Słowa kluczowe: olejek eteryczny, igliwie, strefa korony, wiek drzewa, sosna zwyczajna 